\title{
Local enhancement of epibenthic macrofauna by aquaculture activities
}

\author{
Olivier D'Amours ${ }^{1,2}$, Philippe Archambault ${ }^{1,3, *}$, Christopher W. McKindsey $^{1,3}$, \\ Ladd E. Johnson ${ }^{2}$
}

\author{
${ }^{1}$ Fisheries and Oceans Canada, Institut Maurice-Lamontagne, Environmental Sciences Division, 850 route de la Mer, \\ PO Box 1000, Mont-Joli, Québec G5H 3Z4, Canada \\ ${ }^{2}$ Département de biologie et Québec-Océan, Université Laval, Québec, Québec G1K 7P4, Canada \\ ${ }^{3}$ Institut des sciences de la mer (ISMER), Université du Québec à Rimouski, 310 allée des Ursulines, CP 3300, Rimouski,
} Québec G5L 3A1, Canada

\begin{abstract}
Bivalve aquaculture can influence coastal marine ecosystems by increasing organic material deposition, which, in turn, can have multiple direct and indirect effects on the surrounding benthic community. We assessed the influence of blue mussel Mytilus edulis aquaculture on the epibenthic macrofauna at 4 sites in Prince Edward Island, eastern Canada. The abundance of macroinvertebrates and benthic fishes $(>2 \mathrm{~cm}$ ) was evaluated by visual counts using SCUBA within 4 mussel aquaculture facilities ('farms') and at locations at distances of 50, 100, 500 and $2000 \mathrm{~m}$ outside of them in June, August and November 2005. Benthic assemblages were dominated by seastars Asterias sp. (79\%), rock crabs Cancer irroratus (8\%), mud crabs Neopanope sayi (6\%), moon snails Lunatia heros (2\%), winter flounders Pleuronectes americanus (2\%), American lobsters Homarus americanus $(1 \%)$ and hermit crabs Pagarus sp. $(1 \%)$. Although there was great variability among sites and sampling dates, mussel aquaculture had a clear effect on total abundance, which was generally greater within farms than at distances outside of them. These increases in abundance were mainly associated with increased numbers of seastars and rock crabs. Taxonomic richness and evenness differed among some mussel farms and distances outside of mussel farms, but there were no clear trends that suggested a negative influence of mussel aquaculture. Multivariate analyses indicated that communities within mussel farms differed from those at corresponding communities at distances outside of farms, but that the taxa that contributed to these differences varied among farms. Taxonomic assemblages for a specific farm and date were generally similar among distances outside of farms and increases in the abundance of epibenthic macrofauna appeared to be largely restricted to the immediate vicinity of mussel farms, i.e. $<50 \mathrm{~m}$. This increase in abundance probably reflected the attraction of mobile fauna due to increased food supply and possibly to the creation of a more heterogeneous habitat. These results suggest that large macroinvertebrates and benthic fishes, including ecologically and commercially important species, seem to respond positively to the presence of suspended mussel culture.
\end{abstract}

KEY WORDS: Suspended bivalve aquaculture $\cdot$ Mussel $\cdot$ Environmental impact $\cdot$ Benthic macroinvertebrates $\cdot$ Fish $\cdot$ Diversity

\section{INTRODUCTION}

Aquaculture has expanded significantly over the past decades, leading to increasing concerns about its environmental impacts. Bivalve aquaculture may influence coastal marine ecosystems by locally increasing the deposition of organic material to the seabed, as bivalves filter plankton and detritus and their waste is packaged into large particles (faeces and pseudofaeces) that sink relatively rapidly (Callier et al. 2006). Most studies examining the influence of bivalve aquaculture on the environment have concentrated on the effects of this increased sedimentation of organic matter on physical, chemical and biological (mostly meio- 
faunal and infaunal community structure) properties of the sediments. Observed biological responses to increased organic matter in sediments have often been explained by the eutrophication-response model of Pearson \& Rosenberg (1978) although different conclusions with respect to infaunal community responses have been drawn. Many authors have reported lower diversity of infaunal species (e.g. Mattsson \& Linden 1983, Chamberlain et al. 2001, Hartstein \& Rowden 2004), often a result of increased abundance and dominance of opportunistic species such as polychaetes (e.g. Mattsson \& Linden 1983, Chamberlain et al. 2001, Hartstein \& Rowden 2004, Callier et al. 2007). In contrast, other studies have shown either a neutral (Crawford et al. 2003, Danovaro et al. 2004) or positive (Callier et al. 2008) effect of shellfish aquaculture on meiofaunal or infaunal biomass and diversity. Thus, although the influence of bivalve farms on benthic infaunal communities has been fairly well studied, the potential effects of its most obvious effect (i.e. organic enrichment of aquaculture sites) are not universally observed, possibly due to the wide geographic range of the studies conducted (e.g. Canada, Chile, Australia, Spain) or even the lack of adequate replication in some studies.

Bivalve aquaculture may also have major direct and indirect effects on larger and more mobile epibenthic organisms (i.e. macroinvertebrates and fishes), but relative to infaunal studies, little work has focused on these organisms. The most obvious effect would be a response to an increase or alteration of prey availability. First, the bivalves in culture themselves can provide a new or enhanced source of prey, especially if they are dislodged and fall to the bottom. Second, fouling organisms growing on fallen bivalves may increase both prey abundance and diversity. Third, the alteration of infaunal assemblages by organic enrichment might change resource availability. In addition to trophic effects, aquaculture facilities may serve as artificial reefs as they create 3-dimensional structure (e.g. ropes, anchors, buoys, cages, 'socks') suitable as habitats and refuges for numerous organisms (Costa-Pierce \& Bridger 2002, McKindsey et al. 2006a, Powers et al. 2007). These structures may also be fouled, which, as described previously, can provide additional foraging opportunities for epibenthic predators. Indeed, fouling organisms account for ca. $75 \%$ of the total biomass production of mussel rafts (Stenton-Dozey et al. 1999) and can provide $>400 \mathrm{~g}$ dry weight $\mathrm{m}^{-1}$ of mussel 'sock' (Tenore \& Gonzalez 1975). Earlier studies have shown that fish and mobile invertebrates may be attracted to mussel aquaculture facilities (Morrisey et al. 2006) and, thus, such facilities may influence the spatial and temporal distribution and diet of invertebrates and fish in surrounding areas (Inglis \& Gust 2003).
Observations and biodeposition models have shown that hydrodynamic conditions at a site influence the degree and extent of organic enrichment of the sediment (Hartstein \& Stevens 2005), but it is generally thought that such effects are limited to the area within an aquaculture facility (i.e. the 'farm') or its immediate vicinity. The scales over which bivalve aquaculture influence the environment may then depend on the precise variable studied (e.g. physicochemical features, biodeposition, infaunal or epibenthic assemblages) (Hartstein \& Rowden 2004, Grant et al. 2005, Miron et al. 2005, Richard et al. 2007). For example, the effects of sediment enrichment on infaunal assemblages may be limited to tens of meters whereas the effects on more mobile invertebrates may extend to hundreds of meters. As experimental design is paramount for the detection of environmental changes in impact studies (Underwood \& Chapman 2003), sampling multiple reference locations at multiple spatial scales is required to study the extent of the effects of point sources of disturbance (Archambault et al. 2001, Bishop et al. 2002) such as aquaculture facilities. For example, if sampling locations outside of mussel farms were to be located within the zone influenced by organic deposition related to mussel aquaculture, sampling would be unlikely to detect any influence. Moreover, several previous studies have only compared a single location from within a mussel farm to a single control location outside of it (Grant et al. 1995, Danovaro et al. 2004). Such lack of replication prevents any individual study from distinguishing potential effects of aquaculture from the natural variability in the system. Thus, any study to detect the influence of bivalve farming should ideally have replicated sampling done over multiple spatial scales and be repeated over time to increase generality of any findings.

The general objective of this study was to investigate the influence of blue mussel Mytilus edulis farms on mobile macrobenthic organisms (e.g. fish, lobsters, crabs, seastars). Specifically, we tested 2 hypotheses: (1) the structure and composition of epibenthic macrofaunal assemblages within and outside of mussel farms differ such that the diversity and abundance of these organisms are greatest within farms; and (2) such differences increase with increasing distance from the farms. These hypotheses were evaluated in different seasons to assess the temporal variability in observed patterns.

\section{MATERIALS AND METHODS}

Study sites. Four blue mussel farms located on the north shore of Prince Edward Island, eastern Canada, were studied: 2 in Malpeque Bay (MW and MSE, 
Table 1. Characteristics of study sites and mussel farms on the northern shore of Prince Edward Island (Canada) (data from Fisheries and Oceans Canada, Charlottetown, 2006)

\begin{tabular}{|c|c|c|c|c|}
\hline Bays & $\begin{array}{l}\text { Estimated area (ha) leased for } \\
\text { mussel growth-out (\% of bay area) }\end{array}$ & Sites & Farm location & Farm area (ha) \\
\hline Malpeque & $433.8(3.3)$ & $\begin{array}{l}\text { MW } \\
\text { MSE }\end{array}$ & $\begin{array}{l}46^{\circ} 32^{\prime} 57.627^{\prime \prime} \mathrm{N}, 63^{\circ} 50^{\prime} 53.314^{\prime \prime} \mathrm{W} \\
46^{\circ} 27^{\prime} 51.642^{\prime \prime} \mathrm{N}, 63^{\circ} 43^{\prime} 35.475^{\prime \prime} \mathrm{W}\end{array}$ & $\begin{array}{r}10.5 \\
9.3\end{array}$ \\
\hline Cascumpec & $9.7(0.4)$ & Cas & $46^{\circ} 46^{\prime} 6.308^{\prime \prime} \mathrm{N}, 64^{\circ} 4^{\prime} 15.971^{\prime \prime} \mathrm{W}$ & 9.7 \\
\hline New London & $7.6(16.6)$ & NL & $46^{\circ} 29^{\prime} 31.556^{\prime \prime} \mathrm{N}, 63^{\circ} 27^{\prime} 53.449^{\prime \prime} \mathrm{W}$ & 9.3 \\
\hline
\end{tabular}

located in the western and southeastern portions of this large bay, respectively), one in Cascumpec Bay (Cas) and another in New London Bay (NL) (Table 1; Fig. 1). All farms were located in sheltered areas, 6 to $15 \mathrm{~m}$ deep, favourable for intensive mussel farming using suspended longline systems. These sites were chosen because locations outside of mussel farms with similar conditions (e.g. water depth, currents) were available at various distances from the mussel farms. Water temperature typically ranges from -1 to $24{ }^{\circ} \mathrm{C}$ during the year and the bays are usually ice-covered from late December to April. Each mussel farm comprised up to 14 longlines, each consisting of a $100 \mathrm{~m}$ horizontal surface rope from which mussel socks (numbers and sizes varied among the different farms) were suspended to a depth of 3 to $10 \mathrm{~m}$. Longlines were oriented parallel to the adjacent shoreline and spaced at $10 \mathrm{~m}$ intervals. No harvesting or restocking took place during the study except at MSE, where mussels were harvested in August and restocked in October.

Sampling protocol. Sampling was done during June ( 3 sites excluding NL), August and November (4 sites) 2005 when organic matter production was likely to be greatest due to high metabolic and feeding rates of mussels in the warmer summer and fall conditions. The abundance of mobile macroinvertebrates and benthic fishes $(>2 \mathrm{~cm}$ ) was evaluated at locations within mussel farms and at 4 distances outside of mussel farms (50, 100,500 and $2000 \mathrm{~m}$ from farm edges, hereafter referred to as 'distances'). The rationale for selecting these distances was to examine spatial effects beyond the immediate effects of organic matter deposition (tens of meters; Hartstein \& Stevens 2005, Callier et al. 2006) and at the scale of potential movements of large invertebrates and benthic fishes (hundreds to thousands of meters). Sampling was done at 5 (in June) or 6 (in August and November) locations for each distance outside of the 4 mussel farms and within each farm. At each location, 2 SCUBA divers made underwater visual counts by swimming in pairs along a $50 \times 2 \mathrm{~m}$ transect. One diver swam near the bottom holding a $2 \mathrm{~m}$ pole equipped with a compass while unrolling a measuring tape attached to an anchor block (the transect started $10 \mathrm{~m}$ away from the anchor block to avoid any disturbance created by the block touching the bottom). The second diver swam immediately above the first and counted epibenthic and suprabenthic macroinvertebrates and fish. Underwater visibility ranged from 3 to $6 \mathrm{~m}$ during the sampling periods. Transects within the mussel farms were always per-

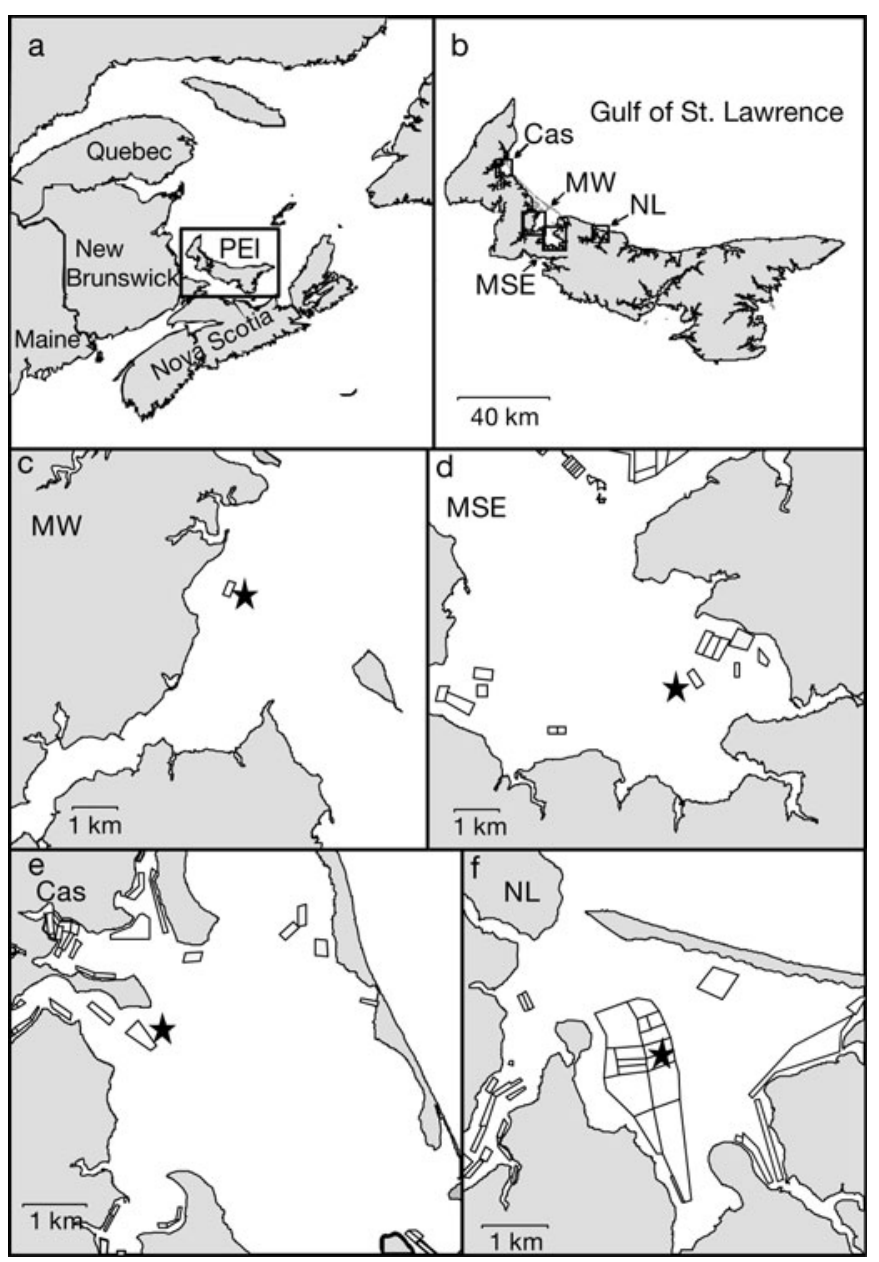

Fig. 1. Location of $(a, b)$ study area in Prince Edward Island (PEI), Canada, and (c-f) mussel farms ( $\star$ ) in Malpeque Bay southeast (MSE) and west (MW) sites, Cascumpec Bay (Cas) and New London Bay (NL) along the island's north coast. Polygons represent bivalve culture sites 
pendicular to the longlines to include areas both under and between the longlines. Transects at distances outside of mussel farms were parallel to the edge of the mussel farms and were located at depths similar to those of the associated farm. Bottom substrata consisted of mud, sand or seagrass beds.

Univariate analyses. Univariate community characteristics (total abundance of macrofauna, taxonomic richness and Pielou's evenness) and abundance of crabs and seastars were examined using a 3-way ANOVA. The 3 factors were Distance (5 levels, fixed; mussel farms $=0 \mathrm{~m})$, Site (3 sites [June] or 4 sites [August and November] levels, random) and Date (3 levels, random) with 5 (June) or 6 (August and November) replicates (i.e. transects) per combination of factor levels. Normality and homoscedasticity were verified by visual inspection of the residuals. In some cases, data were transformed to achieve normality and homoscedasticity (indicated in ANOVA tables). When transformations could not achieve this, analyses were done on untransformed data as ANOVA is robust to small departures from the assumptions of normality and homoscedasticity (Underwood 1997).

Multivariate analyses. All multivariate analyses (statistical and graphical) were based on matrices of Bray-Curtis dissimilarities on untransformed abundance data and presence/absence transformations. Analyses were done using both untransformed data and presence/absence-transformed abundance data, hereafter referred to as 'community structure' and 'taxonomic assemblages', respectively (Thorne et al. 1999). Taxa observed only once were excluded from these analyses.

Variations in community structure and taxonomic assemblages were evaluated using a multivariate dis- tance-based permutational multivariate analysis of variance (PERMANOVA, available from www.stat. auckland.ac.nz/ mja/Programs.htm) with 4999 random permutations of the appropriate units (Anderson 2001). When too few permutations were possible to obtain a reasonable test, a p-value was calculated using 4999 Monte Carlo random samples from the asymptotic permutation distribution (see Terlizzi et al. 2005). Significant factors identified within the full models were further examined using appropriate pairwise comparisons.

Multivariate patterns were visualized using nonmetric multidimensional scaling (nMDS) of dissimilarity matrices for community structure only. To facilitate visualization, nMDS plots show only centroids calculated from the average of 5 (June) or 6 (August and November) transects in each distance-date combination. The taxa that contributed most to separating treatments based on multivariate community structure were identified using the SIMPER procedure with PRIMER (Clarke \& Gorley 2001).

\section{RESULTS}

Benthic communities were dominated numerically by seastars Asterias sp. (79\%) with other taxa each accounting for less than $10 \%$ of the total abundance; i.e. rock crab Cancer irroratus (8\%), mud crab Neopanope sayi $(6 \%)$, moon snail Lunatia heros ( $2 \%)$, winter flounder Pleuronectes americanus (2\%), American lobster Homarus americanus (1\%) and hermit crab Pagarus sp. $(1 \%)$. A few other taxa (e.g. sand shrimp Crangon septemspinosa, threespine stickleback Gasterosteus aculeatus, and longhorn sculpin Myoxocephalus

Table 2. Summary of ANOVA of univariate community characteristics (abundance of all individuals and of the 2 most abundant species, taxonomic richness and evenness) to test the effects of Date, Site, Distance and their interactions. Transformations, when applied, are indicated in parentheses. ${ }^{a}$ The denominator MS are indicated for each source of variation. nt $=$ no test

\begin{tabular}{|c|c|c|c|c|c|c|c|c|c|c|c|c|c|c|c|c|}
\hline \multirow[t]{2}{*}{$\begin{array}{l}\text { Source } \\
\text { of variation }\end{array}$} & \multirow[t]{2}{*}{$\mathrm{df}$} & \multicolumn{3}{|c|}{$\begin{array}{c}\text { Total } \\
\text { individuals } \\
\left(\log _{10}+1\right)\end{array}$} & \multicolumn{3}{|c|}{$\begin{array}{l}\text { Cancer irroratus } \\
\text { abundance } \\
\left(\log _{10}+1\right)\end{array}$} & \multicolumn{3}{|c|}{$\begin{array}{c}\text { Asterias sp. } \\
\text { abundance } \\
\left(\log _{10}+1\right)\end{array}$} & \multicolumn{3}{|c|}{$\begin{array}{l}\text { Taxonomic } \\
\text { richness } \\
\text { (square root) }\end{array}$} & \multicolumn{3}{|c|}{$\begin{array}{c}\text { Evenness } \\
\text { (square root) }\end{array}$} \\
\hline & & MS & $F$ & $\mathrm{p}$ & $\mathrm{MS}$ & $F$ & $\mathrm{p}$ & $\mathrm{MS}$ & $F$ & $\mathrm{p}$ & MS & $F$ & $\mathrm{p}$ & MS & $F$ & $\mathrm{p}$ \\
\hline Date (Da) & 2 & 1.325 & 1.07 & 0.36 & 1.857 & 2.12 & 0.2 & 10.524 & 13.24 & 0.09 & 6.004 & 103.25 & 0.19 & 2.288 & 11.13 & 0.02 \\
\hline Site $(\mathrm{Si})$ & 3 & 2.567 & 3.15 & 0.1 & 9.549 & 11.04 & 0.002 & 3.295 & 6.09 & 0.06 & 0.068 & 1.02 & 0.46 & 0.392 & 2.57 & 0.13 \\
\hline Distance (Di) & 4 & nt & nt & nt & nt & nt & nt & nt & nt & nt & nt & nt & nt & nt & nt & nt \\
\hline $\mathrm{Da} \times \mathrm{Si}$ & 5 & 0.861 & 2.86 & 0.04 & 0.584 & 11.49 & $<0.0001$ & 0.585 & 0.87 & 0.52 & 0.097 & 0.86 & 0.53 & 0.128 & 2.96 & 0.04 \\
\hline $\mathrm{Da} \times \mathrm{Di}$ & 8 & 0.456 & 1.14 & 0.37 & 0.129 & 2.48 & 0.11 & 0.917 & 1.01 & 0.43 & 0.081 & 0.57 & 0.69 & 0.088 & 1.62 & 0.22 \\
\hline $\mathrm{Si} \times \mathrm{Di}$ & 12 & 0.493 & 2.53 & 0.04 & 0.558 & 11.24 & $1<0.0001$ & 0.591 & 1.41 & 0.24 & 0.076 & 0.91 & 0.52 & 0.104 & 3.37 & 0.01 \\
\hline $\mathrm{Da} \times \mathrm{Si} \times \mathrm{Di}$ & 20 & 0.301 & 5.76 & $<0.0001$ & 0.051 & 1.06 & 0.4 & 0.672 & 8.74 & $<0.0001$ & 0.113 & 2.74 & 0.0001 & 0.043 & 3.02 & $<0.0001$ \\
\hline Residual & 260 & 0.052 & & & 0.048 & & & 0.077 & & & 0.041 & & & 0.014 & & \\
\hline
\end{tabular}


octodemspinosus) were also observed, but they were not included in the analyses as they could not be accurately recorded due to their small size or high mobility.

\section{Univariate analyses}

There were significant 3-way interactions between Date, Site and Distance for total abundance of epibenthic macrofauna, abundance of the Asterias sp., taxonomic richness and Pielou's evenness, and a Site $\times$ Distance interaction for the abundance of the crab (Cancer irroratus) (Table 2). Overall, although there was great variability among sites and dates, blue mussel aquacul- ture had a clear effect on total abundance. Total abundance at the mussel farms was significantly greater than at least one distance and usually all distances (8 of the 11 Site-Date combinations, Fig. 2). There was usually a 2- to 4-fold higher abundance in macrofauna within mussel farms relative to distances outside of mussel farms and an exceptional 10-fold greater total abundance at MSE in August, coinciding with the period just after mussel harvesting. There were only 2 cases where distances outside of mussel farms differed significantly in abundance for a given site and date, both in November. The abundance of both $C$. irroratus and Asterias sp. within mussel farms was greater relative to most distances outside of mussel farms in most
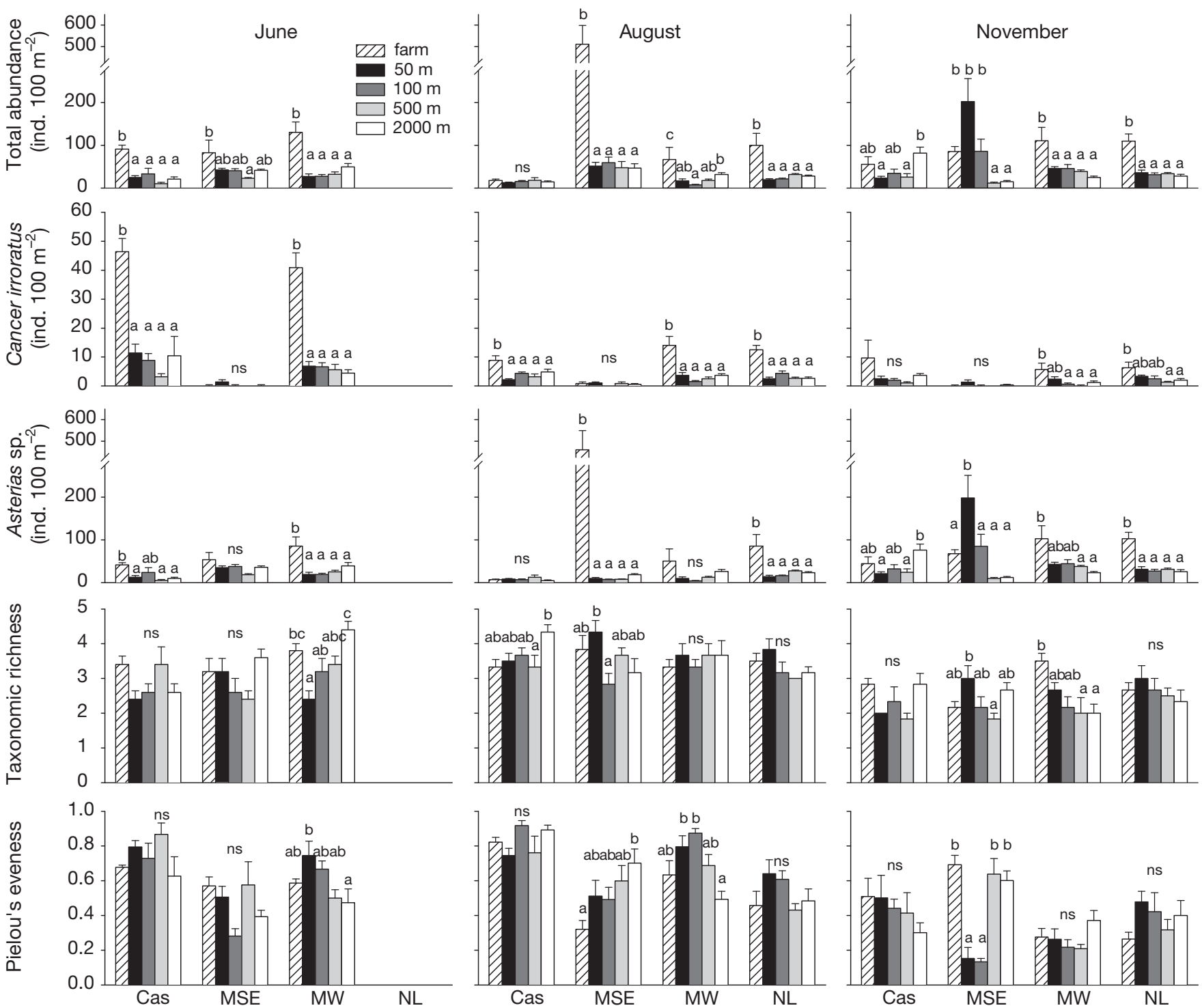

Fig. 2. Mean $( \pm \mathrm{SE})$ abundance of all macrofauna (total abundance) and that of the 2 dominant taxa as well as taxonomic richness and Pielou's evenness in mussel farms at Cascumpec (Cas), Malpeque Bay Southeast (MSE), Malpeque Bay West (MW) and New London Bay (NL) and at 4 distances outside of each farm (50, 100, 500 and $2000 \mathrm{~m}$ ) in June, August and November 2005. Different letters above bars indicate a significant difference between distances at a given site and date; Tukey's tests, $\mathrm{p}<0.05 ; \mathrm{ns}=\mathrm{not}$ significant 
cases ( 7 and 6 of 11 Site-Date comparisons, respectively; Fig. 2). The 4 exceptions for $C$. irroratus included all 3 dates at MSE, where this species was much less common, and one date at Cas when the crab was nonetheless 4 -fold more abundant within the mussel farms than at the distances outside of mussel farms, but there was high variability among transects. For Asterias sp., there were no obvious patterns although one noteworthy exception occurred at MSE in November when seastar abundance at $50 \mathrm{~m}$ from the mussel farm was al- most 3-fold higher than either within the mussel farm or at other distances. This pattern differed strikingly from the previous sampling of this mussel farm in August when seastar abundance within the mussel farm was an order of magnitude more abundant than any distance outside the mussel farm. Indeed, given the low abundance of $C$. irroratus at this site (Fig. 2), the high abundance of Asterias sp. at the mussel farm at MSE in August explains the high total abundance of macrofauna observed there at that time.

Table 3. Summary of PERMANOVA analysis based on Bray-Curtis similarities of community structure (untransformed abundance data) and taxonomic assemblages (presence/absence data) to test the effects of Date, Site, Distance and their interactions.

$$
\mathrm{nt}=\text { no test }
$$

\begin{tabular}{|c|c|c|c|c|c|c|c|}
\hline \multirow{2}{*}{$\begin{array}{l}\text { Source } \\
\text { of variation }\end{array}$} & \multirow[t]{2}{*}{ df } & \multicolumn{3}{|c|}{ Community structure } & \multicolumn{3}{|c|}{ Taxonomic assemblage } \\
\hline & & MS & Pseudo- $F$ & Monte Carlo (p) & MS & Pseudo- $F$ & Monte Carlo (p) \\
\hline Date (Da) & 1 & 61554 & 5.44 & 0.0036 & 28595 & 5.86 & 0.0272 \\
\hline Site $(\mathrm{Si})$ & 2 & 31356 & 2.95 & 0.0174 & 36048 & 7.87 & 0.0082 \\
\hline Distance (Di) & 4 & nt & nt & nt & nt & nt & nt \\
\hline $\mathrm{Da} \times \mathrm{Si}$ & 5 & 10783 & 14.83 & 0.0002 & 4652 & 16.57 & 0.0002 \\
\hline $\mathrm{Da} \times \mathrm{Di}$ & 4 & 4756 & 1.75 & 0.0476 & 272 & 0.41 & 0.9684 \\
\hline $\mathrm{Si} \times \mathrm{Di}$ & 8 & 3663 & 1.41 & 0.0938 & 903 & 1.36 & 0.199 \\
\hline $\mathrm{Da} \times \mathrm{Si} \times \mathrm{Di}$ & 20 & 2616 & 3.60 & 0.0002 & 672 & 2.39 & 0.0002 \\
\hline Residual & 260 & 727 & & 281 & & & \\
\hline
\end{tabular}

Table 4. Multivariate pairwise comparisons among distances at each site (mussel farm $=0$ ) and sampling period for community structure (untransformed abundance data) and taxonomic assemblages (presence/absence data). For brevity, only significant differences are indicated $\left({ }^{*} \mathrm{p}<0.05,{ }^{* *} \mathrm{p}<0.01,{ }^{* * *} \mathrm{p}<0.005\right)$

\begin{tabular}{|c|c|c|c|c|c|c|c|c|c|c|c|c|}
\hline \multirow[t]{2}{*}{ Comparisons } & \multicolumn{3}{|c|}{ Cascumpec } & \multicolumn{3}{|c|}{ Malpeque SE } & \multicolumn{3}{|c|}{ Malpeque West } & \multicolumn{3}{|c|}{ New London } \\
\hline & Jun & Aug & Nov & Jun & Aug & Nov & Jun & Aug & Nov & Jun & Aug & Nov \\
\hline \multicolumn{13}{|c|}{ Community structure } \\
\hline 0 vs $50 \mathrm{~m}$ & $* *$ & $* * *$ & & $* * *$ & $* *$ & ** & $*$ & & no data & $* * *$ & $* * *$ & \\
\hline 0 vs $100 \mathrm{~m}$ & $* *$ & $*$ & & $* * *$ & & $* *$ & $* * *$ & & $* * *$ & $* * *$ & & \\
\hline 0 vs $500 \mathrm{~m}$ & $* *$ & * & & $*$ & $* * *$ & $* * *$ & $* *$ & * & $*$ & & $* *$ & $* * *$ \\
\hline 0 vs $2000 \mathrm{~m}$ & $*$ & $*$ & & $* * *$ & $* * *$ & $*$ & $* *$ & & $* *$ & $* * *$ & & \\
\hline 50 vs $100 \mathrm{~m}$ & & ${ }^{*}$ & & & & & & & & & & \\
\hline 50 vs $500 \mathrm{~m}$ & $*$ & & $*$ & $* * *$ & & & & $* *$ & & & & \\
\hline 50 vs $2000 \mathrm{~m}$ & & $* *$ & $* *$ & & $* * *$ & & $*$ & & $*$ & & & \\
\hline 100 vs $500 \mathrm{~m}$ & & & ${ }^{* *}$ & $* * *$ & & $* *$ & $* *$ & & $* * *$ & & & \\
\hline 100 vs $2000 \mathrm{~m}$ & & & & $*$ & $* * *$ & $*$ & $* * *$ & & $*$ & & & \\
\hline 500 vs $2000 \mathrm{~m}$ & & $*$ & ** & & & * & $* *$ & & & & & \\
\hline \multicolumn{13}{|c|}{ Taxonomic assemblages } \\
\hline 0 vs $50 \mathrm{~m}$ & & & & & * & & no data & * & & & & \\
\hline 0 vs $100 \mathrm{~m}$ & & & & $* * *$ & & * & * & & $*$ & & & \\
\hline 0 vs $500 \mathrm{~m}$ & & $*$ & & $* * *$ & & & $* *$ & & & & & \\
\hline 0 vs $2000 \mathrm{~m}$ & $*$ & ${ }^{*}$ & * & & ** & & $* *$ & ${ }^{* *}$ & & & & \\
\hline 50 vs $100 \mathrm{~m}$ & & & & $* *$ & & * & $*$ & & & & & \\
\hline 50 vs $500 \mathrm{~m}$ & & & & $*$ & * & $*$ & $* *$ & & $*$ & & & \\
\hline $50 \mathrm{vs} 2000 \mathrm{~m}$ & & & & $*$ & & $* *$ & $*$ & & & & & \\
\hline 100 vs $500 \mathrm{~m}$ & & * & & & & $*$ & & & & & & \\
\hline 100 vs $2000 \mathrm{~m}$ & & & & & $* *$ & & & & & & & \\
\hline 500 vs $2000 \mathrm{~m}$ & & & & $*$ & & & & & & & & \\
\hline
\end{tabular}


Overall, mean taxonomic richness varied between 1.8 and 4.4 taxa per transect. Taxonomic richness differed among distances at MW in June, at Cas and MSE in August, and at MSE and MW in November, but there were no clear trends of a particular distance being richer in taxa than in another (Fig. 2). Pielou's evenness also differed among distances in 4 of the 11 Site-Date comparisons (Fig. 2), but there were no differences between mussel farms and distances outside of them nor was there a general pattern with respect to a particular distance having a greater degree of evenness than another.

\section{Multivariate analyses}

Generally, community structure and taxonomic assemblages of mobile epibenthic macrofauna at mussel farms differed from those sampled at distances outside of corresponding mussel farms. However, interpretations are not straightforward as there were significant interactions between Date, Site and Distance (Table 3). With respect to community structure, 9 of 11 possible Site-Date combinations showed that community structure in mussel farms differed from that at distances outside of mussel farms, which typically did not differ among themselves (Table 4). When compared by individual dates, nMDS shows that community structure of epifauna within mussel farms differed greatly between farms and from that at distances outside of farms in June and August, but less so in November (Fig. 3). SIMPER analysis showed that a small number of taxa accounted for $>90 \%$ of the dissimilarity between mussel farms and distances outside of mussel farms. In order of importance, these included Asterias sp. and Cancer irroratus at MW and NL (all dates), Asterias sp. and Lunatia heros at MSE (all dates) and C. irroratus and Asterias sp. for Cas (June and August). All of these taxa were most abundant within mussel farms.

Pairwise comparisons of mussel farms and distances outside of mussel farms for each Site-Date combination showed that taxonomic assemblages differed mostly at MSE in August and at MW in June and November (Table 4). The taxa most responsible (SIMPER analysis) for these differences (together accounting for $>80 \%$ of the total dissimilarity) in taxonomic assemblages at the mussel farm in MSE in August were Lunatia heros and Pleuronectes americanus, which were more and less abundant, respectively, relative to distances outside of farms. At MW, the abundance of $P$. americanus and Homarus americanus in June and the abundance of these same 2 species and of Cancer irroratus in August were greater in the farm than at distances outside of mussel farms.

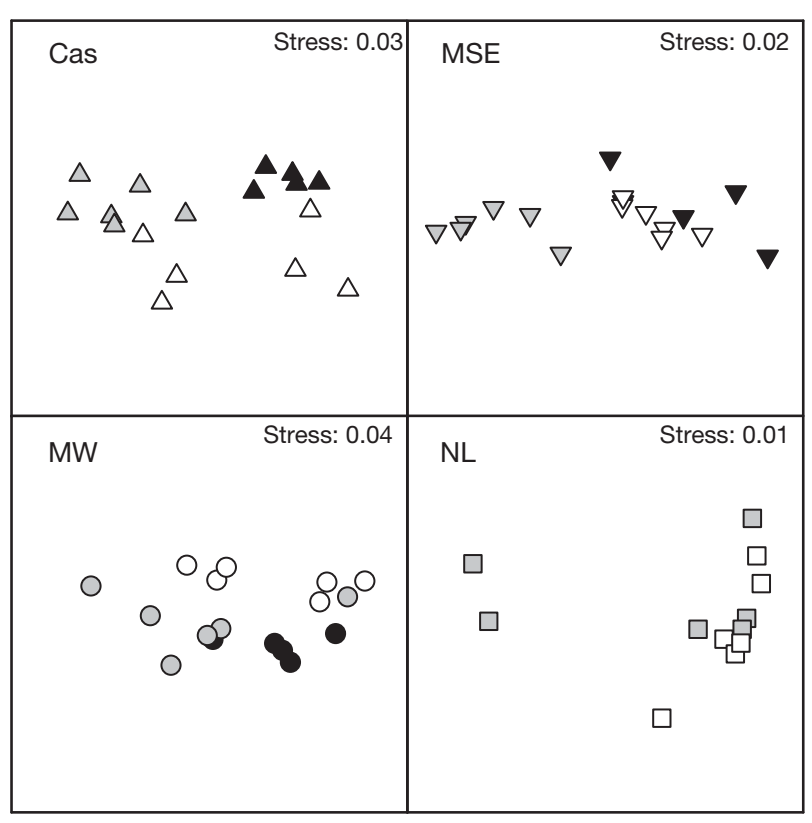

Fig. 3. Nonmetric multi-dimensional scaling plots (nMDS) of macroinvertebrate and fish community structure at different sampling dates in June (solid black symbols), August (solid grey symbols) and November (open symbols) 2005 in mussel farms in Cascumpec Bay (Cas), Malpeque Bay Southeast (MSE), Malpeque Bay West (MW) and New London Bay (NL)

\section{Comparison of macrofaunal community structure among mussel farms}

Pairwise comparisons indicated clear differences in epifaunal community structure among mussel farms in each sampling period (Fig. 4). In June, mussel farms differed significantly overall $\left(F_{2,14}=17.9, \mathrm{p}<0.001\right)$ such that MSE differed from Cas $(p=0.002)$ and MW $(p=0.0102)$. SIMPER indicated that this difference was due to the very low density of Cancer irroratus at MSE (average 0.2 individuals [ind.] $100 \mathrm{~m}^{-2}$ ) compared with high densities at Cas and MW (46 and 40 ind. $100 \mathrm{~m}^{-2}$, respectively) (Fig. 2). The abundance of Lunatia heros (average, 26 ind. $100 \mathrm{~m}^{-2}$ ) was greatest at MSE and accounted for about $20 \%$ of the dissimilarity between this site and both Cas and MW. Significant overall differences were also seen in August when pairwise comparisons detected significant differences between all mussel farm pairs (all $\mathrm{p}<0.010$ ) except between MW and NL ( $p=0.28)$. SIMPER indicated that the high abundance of Asterias sp. (average, 460 ind. $100 \mathrm{~m}^{-2}$ ) at the mussel farm at MSE, which had just been harvested, explained more than $80 \%$ of the dissimilarity between this and the other farms. The relatively greater abundance of Neopanope sayi in MSE (average, 33 ind. $100 \mathrm{~m}^{-2}$ ) relative to other sites explained an additional $8 \%$ of dissimilarity between farms. 


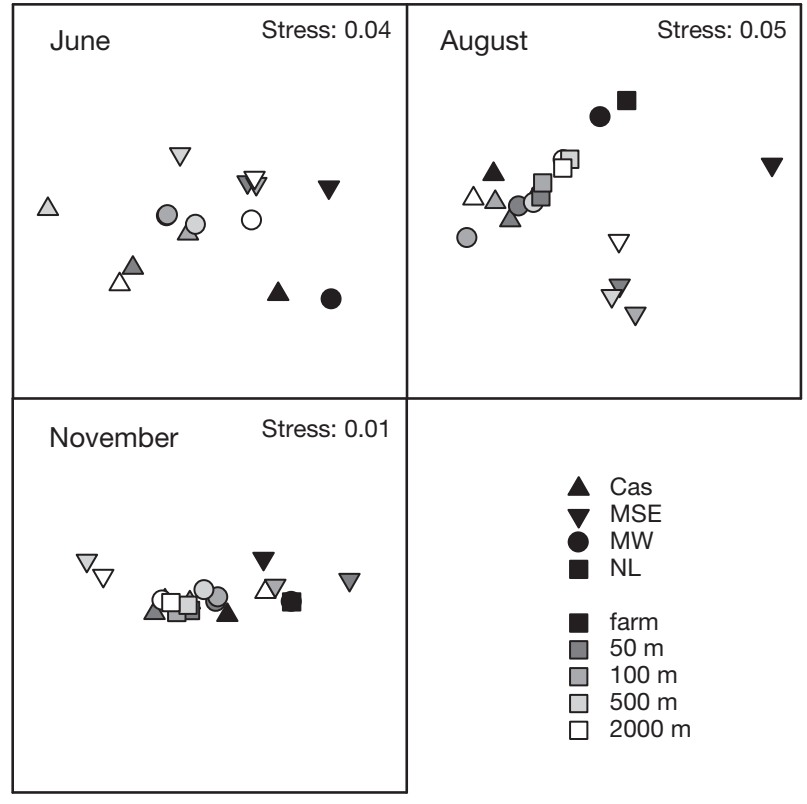

Fig. 4. Nonmetric multi-dimensional scaling plots (nMDS) of centroids for community structure based on macroinvertebrate and fish taxa densities in June, August and November 2005 from sampling inside mussel farms (0), and at 4 distances $(50,100,500$ and $2000 \mathrm{~m})$ outside of mussel farms in Cascumpec Bay (Cas), Malpeque Bay Southeast (MSE), Malpeque Bay West (MW) and New London Bay (NL)

Differences between Cas and the other farms are explained by the relatively low abundance of Asterias sp. (average, 6.7 ind. $100 \mathrm{~m}^{-2}$ ) and C. irroratus (average, 8.8 ind. $100 \mathrm{~m}^{-2}$ ) in Cas. Although the November nMDS plot showed greater overlap of the mussel farms (Fig. 3), overall differences among mussel farms were still detected such that the community at MSE differed significantly from all other mussel farms (all $\mathrm{p} \leq 0.05$ ) and CAS differed from NL $(p=0.036)$. Again, the relatively greater abundance of $L$. heros in MSE (average, 17.8 ind. $100 \mathrm{~m}^{-2}$ ) had a strong influence on overall dissimilarity. Further, the relatively low density of Asterias sp. at MSE (average, 67.5 ind. $100 \mathrm{~m}^{-2}$ ) contributed considerably to differences between this site and MW and NL (average, 103 ind. $100 \mathrm{~m}^{-2}$ ) but less so for Cas (average, 44.5 ind. $100 \mathrm{~m}^{-2}$ ). About $90 \%$ of the dissimilarity between Cas and NL is attributed to differences in the abundance of Asterias sp.

\section{Temporal variability of epifaunal community structure at mussel farms}

Epifaunal communities varied over time at all sites except NL (Fig. 4). Assemblages at Cas differed among all dates (June and August, $p=0.002$; June and
November, $\mathrm{p}=0.027$; August and November, $\mathrm{p}=$ 0.004), largely due to changes in the abundance of Cancer irroratus and Asterias sp. (together accounting for $>90 \%$ of the dissimilarity between dates). Cancer irroratus was very abundant in June (average, 46 ind. $100 \mathrm{~m}^{-2}$ ) and decreased to low levels in August and November (average, 8.8 and 9.7 ind. $100 \mathrm{~m}^{-2}$, respectively). The abundance of Asterias sp. was greater in June and November (average, 41 and 44 ind. $100 \mathrm{~m}^{-2}$, respectively) than in August (6.7 ind. $100 \mathrm{~m}^{-2}$ ). At MSE, the epifaunal community changed between June and August ( $p=0.0008)$ and again between August and November $(\mathrm{p}=0.002)$. There was a greater density of Asterias sp. (average, 460 ind. $100 \mathrm{~m}^{-2}$ ) in August than in June and November (average, 53 and 67 ind. $100 \mathrm{~m}^{-2}$, respectively). In addition, Neopanope sayi was only present in August (average, 33 ind. $100 \mathrm{~m}^{-2}$ ). Based on pairwise comparisons, communities at MW only differed between June and August ( $p=0.042)$. SIMPER indicated that the taxa responsible for this were Asterias sp. and C. irroratus, accounting for $68 \%$ and $29 \%$, respectively, of the overall dissimilarity between dates. Both taxa were more abundant in June than in August.

\section{DISCUSSION}

This study demonstrated a clear influence of blue mussel aquaculture on communities of benthic macroinvertebrates and fishes. Univariate and multivariate analyses both revealed that the differences between mussel farms and distances outside of mussel farms were largely a result of an increased abundance of a variety of organisms in the vicinity of the mussel farms. Overall, the taxa that accounted for most of the differences in abundance and community structure were the seastar Asterias sp., the crab, Cancer irroratus, and the gastropod, Lunatia heros. At times, the winter flounder Pleuronectes americanus and the American lobster Homarus americanus contributed to such differences as they were present at mussel farms, but absent from distances outside of mussel farms. In contrast, mussel aquaculture did not have any detectable influence on taxonomic richness or evenness or on community assemblages.

Other studies have also reported increased densities of benthic predators at mussel farms relative to areas outside of mussel farms. As with our study, Inglis \& Gust (2003) found a large increase (14- to 39-fold) in abundance of the seastar, Coscinasterias muricata, at mussel farms relative to control sites in New Zealand. Olaso (1982) observed a 10-fold increase in the biomass of echinoderms (mostly seastars, but also sea urchins and sea cucumbers) within mussel farms in 
Spain relative to control areas. Our results showed that this increase in density was not limited to seastars as the rock crab Cancer irroratus was also more abundant at locations within mussel farms relative to distances outside of mussel farms. Such an effect was also observed by Romero et al. (1982) who reported that the abundance of 3 crab species increased up to 6-fold at mussel raft sites relative to control sites in Spain. González-Gurriarán (1986) demonstrated a similar pattern for a single crab species, again in Spain. In the present study, the abundance of the gastropod, Lunatia heros, in mussel farms was 10-fold greater within mussel farm relative to distances outside of mussel farms. Grant et al. (1995) also found increased biomass of the predatory gastropods, Ilyanassa spp. and Nucula tenuisucata, at a mussel farm in Nova Scotia, eastern Canada.

This increase of benthic predators at mussel farms is probably related to increased food supply. This may be a direct result of mussels falling from mussel lines providing food or else an indirect effect of epifauna associated with mussel lines falling off. Further, indirect increases in food availability may also arise by the accumulation of empty mussel shells ('shell hash') on the bottom resulting from mussels inadvertently falling off lines and nets (de Jong 1994), thereby creating a permanent habitat for species able to live on or within the shells (McKindsey et al. 2006a). In addition, structures added to the water column for aquaculture purposes (e.g. ropes, anchors, buoys, mussel 'socks') also create surfaces for colonization by epifauna (Morrisey et al. 2006), thus potentially supplying further food sources to predatory species in mussel culture sites. Finally, changes in infaunal assemblage due to increased deposition of organic material under and adjacent to mussel farms may provide additional or alternate food resources.

A number of studies have documented the influence of such increases in food supply resulting from mussel aquaculture. González-Gurriarán (1986) and Freire \& González-Gurriarán (1995) showed that mussel rafts constituted an important source of food for crabs. Likewise, Romero et al. (1982) showed that increased crab density was associated with the abundance of food from sessile epifaunal species and biodeposition. Olaso (1982) also observed seastars feeding on mussels that had fallen from these rafts. Indeed, Inglis \& Gust (2003) demonstrated a correlation between the abundance of the seastar, Coscinasterias muricata, and the density of live mussels on the seafloor, which had probably fallen from longlines. Within the mussel farms, we observed clumps of live mussels and shell material with their associated fauna almost exclusively directly beneath the longlines. These bottom reef-like structures can attract large numbers of pelagic and epibenthic preda- tors due to the presence of their preferred prey (Mattsson \& Linden 1983), and several taxa observed in our study could have exploited this resource. Asterias sp. is a benthic predator that will preferentially select mussels (Gaymer et al. 2001), and predation by this taxon has caused problems in mussel aquaculture operations (O'Neill et al. 1983). Similarly, Cancer irroratus will feed on the dominant epifaunal and infaunal species with its most common prey being molluscs and polychaetes (Stehlik 1993). Likewise, the presence of Lunatia heros, an actively foraging predator of molluscs, particularly bivalves (Commito 1982), can be explained by the abundance of mussels clumps on the seafloor at these mussel farms. Finally, higher abundances of Homarus americanus within farms can also be explained simply by the large quantities of mussels falling off longlines or possibly by the increased abundance of $C$. irroratus (Pearson $r=0.539, p<0.001$ ), one of its preferred prey (Sainte-Marie \& Chabot 2002).

Numerous studies have observed increased abundances of opportunistic infaunal species related to the presence of suspended bivalve culture (Grant et al. 1995, Chamberlain et al. 2001, Hartstein \& Rowden 2004, Callier et al. 2006). An increased abundance of opportunistic species may in turn increase the abundance of larger predatory species. For example, Pleuronectes americanus was more abundant at some mussel farms than at others, possibly reflecting an increased abundance of opportunistic infaunal and epifaunal species, such as polychaetes and amphipods (Howell et al. 1999), which are prey to this benthic fish species. Clynick et al. (2008) observed a greater abundance of $P$. americanus in mussel farm sites in the Magdalen Islands, eastern Canada, than in surrounding eelgrass Zostera marina beds, which could be related to the high abundance of opportunistic infaunal species found at the same study sites (Callier et al. 2006).

Finally, the structural components of the mussel farm increase habitat complexity and could serve as refuges for certain epibenthic species. In the sites studied, one of the most likely species to be affected is Homarus americanus, which uses refuges to increase survival and growth (Paille et al. 2002). Indeed, we observed that lobsters were often closely associated with the cement blocks that serve as anchors for the longlines.

To date, most studies on the effects of suspended bivalve aquaculture have compared benthic communities associated with mussel farms to single control sites (Grant et al. 1995, Danovaro et al. 2004, Hartstein \& Rowden 2004). Only a few studies have tried to determine the scale of any effect (i.e. the distance at which mussel aquaculture no longer has any significant effect) (Mattsson \& Linden 1983, Chamberlain et al. 2001, Crawford et al. 2003, Callier et al. 2006). In the 
present study, there was no detectable effect of the farm, either positive or negative, at the distance nearest to mussel farms (i.e. $50 \mathrm{~m}$ ). That is, communities at $50 \mathrm{~m}$ did not differ from those at greater distances outside of mussel farms. This result, together with the observation that most fauna observed in farms were directly below the lines and not between them, indicates that the effect (or outcome) of the attraction of organisms at mussel farms is likely localized to areas within and possibly immediately adjacent to mussel farms (i.e. $<50 \mathrm{~m}$ ).

As discussed previously, the higher abundance of epibenthic macrofauna within mussel farms is probably due to the greater food resources provided by the mussel farms, although greater densities could also be due to higher recruitment of planktonic larvae or movements of juveniles or adults from adjacent areas. Given the lengthy planktonic period of the larval stages of the species observed, it is unlikely that there was any retention of locally produced offspring. However, increases in population densities within aquaculture facilities could nonetheless increase total reproduction output on a bay-wide scale both by increasing gonad growth and external fertilization success (through closer proximity of individuals) (Inglis \& Gust 2003).

Given the high mobility and generally large size of individuals observed at the mussel farms (O. D'Amours unpubl. data), it is more likely that higher densities within mussel farms are due to the accumulation of juvenile or mature individuals that either wandered into or were attracted to these areas. Our data do not suggest any local depletion of adjacent populations (i.e. lower densities at the $50 \mathrm{~m}$ distance outside of mussel farm relative to greater distances). This is not surprising given that the mussel farms are permanent structures and have been in place long enough to attain a quasi-equilibrium state. Moreover, repeated sampling over time confirmed that the general pattern of greater abundance of epibenthic macrofauna within mussel farms was temporally stable (at least over a 6 mo period) although there were differences for certain taxa, suggesting that system is actually quite dynamic.

Such a dynamic response by epibenthic predators was demonstrated at the MSE site where mussel harvesting took place just before the August sampling. During the harvest operations, large quantities of organisms (mussel and epifauna) were undoubtedly detached from the longlines, increasing food availability for epibenthic predators. This increased biomass on the seabed appeared to have attracted large numbers of epibenthic predators, in particular Asterias sp., which was almost 10 -fold more abundant within the mussel farm than at distances outside it. This increase had a significant effect on the community characteristics (multivariate structure, evenness, and total number of individuals). By the time of our last sampling in November, farmers had restocked mussel socks with juvenile mussels $(\sim 1 \mathrm{~cm}$ shell length). However, the greater abundance of Asterias sp. at intermediate distances $(50$ and $100 \mathrm{~m})$ suggests that the seastars had been dispersing away from the mussel farm over the 3 mo after harvesting.

During the SCUBA surveys, a large number of predators were observed directly around anchor blocks and beneath mussel socks, but relatively few were in the $10 \mathrm{~m}$ wide areas between the longlines. Such small-scale influences on community structure have also been observed for infaunal communities, which differed between positions directly below mussel lines relative to those between mussel lines (Callier et al. 2007). This $10 \mathrm{~m}$ scale pattern for infauna is likely due to sedimentation patterns related to bivalve biodeposition, which varies at the same spatial scale (Callier et al. 2006). In fact, most studies on biodeposit dispersion have shown that it is usually limited to areas $<50 \mathrm{~m}$ from mussel farms and is a function of biodeposit settling velocity, water depth and current velocity (Chamberlain et al. 2001, Hartstein \& Stevens 2005, Callier et al. 2006).

In contrast to biodeposits, mussels and biofoulers are likely to settle much more quickly and accumulate directly under mussel lines. Indeed, de Jong (1994) reported distinct piles of mussel shells directly under mussel lines in New Zealand, and these seemed to support an assemblage more typical of hard bottoms. Likewise, in studies examining artificial reefs (Sanchez-Jerez \& Ramos-Espla 2000) and fish farms (Dempster et al. 2002), steep declines in the abundance of organisms were observed starting from just a few meters away from the structures. In a study on artificial reefs in Canada, Sargent et al. (2006) observed increases of some species of marine invertebrates and fish at scales less than $20 \mathrm{~m}$ around reef structures.

The overall influence of mussel aquaculture on benthic communities is likely to be affected by a number of factors such as local primary production, hydrodynamic features of the site, size, biomass and age of the shellfish farm (Grant et al. 2005, Miron et al. 2005). Results from our study showed significant differences in the composition and structure of the epibenthic macrofaunal component of benthic communities at the different mussel farms. MSE often differed most from the other mussel farms although this may be partly explained by the husbandry operations that took place there (see previous discussion). However, taxonomic assemblages at MSE were also quite different from those at other mussel farms, mostly due to the presence of Lunatia heros and Neopanope sayi at MSE. The 
composition of epibenthic macrofaunal communities at mussel farms may depend on the available pool of species in the area and the suitability of a mussel farm (including the bottom type) as habitat for each species. MSE also had very low numbers of Cancer irroratus during all sampling dates as compared with the other mussel farms, suggesting that the habitat is less suitable for this species. Alternately, a minor fishery for C. irroratus in the surrounding area may also account for the lower abundance of this species in MSE.

Temporal differences in these assemblages were also observed at all mussel farms over the 6 mo of study. However, these differences were relatively insignificant in comparison with the overall enhancement effect of mussel aquaculture. The temporal variations in the distribution of specific organisms are most probably linked with changes in water temperature (Reiss \& Kroncke 2004). The high variability in water temperature during our study (June, $13^{\circ} \mathrm{C}$; August, $19^{\circ} \mathrm{C}$; November, $8^{\circ} \mathrm{C}$ ) may account for the change in abundance of certain taxa. Asterias sp. and Cancer irroratus, the 2 principal predators, were more abundant in June and November than in August except for in MSE when harvesting took place in August. Stehlik et al. (1991) observed that the distribution of Cancer spp. was affected by temperature such that their preferred range was from 3 to $13^{\circ} \mathrm{C}$. However, this aspect was not specifically tested in the present study and remains to be explored in more detail.

For suspended bivalve culture to be sustainable and properly regulated, the potential effects of the practice on different components of the environment, as well as the scale and variability of these effects, must be better understood and defined (McKindsey et al. 2006b). The present study suggests that large macroinvertebrates and benthic fishes, including ecologically and commercially important species, seem to respond positively to the presence of suspended mussel culture. Given the great extent of mussel and other bivalve culture worldwide and the potential growth of the industry, the overall effect of this practice on the productivity of such species may be considerable. Thus, these organisms should be included in monitoring programs for bivalve aquaculture and when examining the ecological carrying capacity of an area for this activity so that a more holistic understanding of the role of bivalve aquaculture in the environment may be attained. This information is essential to consider sustainable solutions to the environmental challenges facing the aquaculture industry.

Acknowledgements. The authors thank F. Hartog, P. Robichaud, L. Robichaud, C. Langevin and C. Godboudt for their precious help in the field. We also thank the mussel growers (Cabot Seafoods Inc., B.J. Mussel Farms Ltd., Fraser's Harbourview Ltd. and M.R.S. Mussel Ltd.) who allowed us to work in their sites and to the Prince Edward Island Aquaculture Alliance for support throughout the project. The authors are grateful to Fisheries and Oceans Canada (Mont-Joli) for boat and diving facilities. This study was funded by AquaNet (a Natural Sciences and Engineering Research Council Network of Centres of Excellence in Aquaculture) to C.W.M. and P.A., and from Fisheries and Oceans Canada, Société de développement de l'industrie maricole, the Aquaculture Collaborative Research and Development Program and the Réseau Aquaculture Québec (RAQ). O.D. was supported by Fonds Québécois de la Recherche sur la nature et les technologies, Québec-Océan, and RAQ scholarships.

\section{LITERATURE CITED}

Anderson MJ (2001) Permutation tests for univariate or multivariate analysis of variance and regression. Can J Fish Aquat Sci 58:626-639

Archambault P, Banwell K, Underwood AJ (2001) Temporal variation in the structure of intertidal assemblages following the removal of sewage. Mar Ecol Prog Ser 222:51-62

> Bishop MJ, Underwood AJ, Archambault P (2002) Sewage and environmental impacts on rocky shores: necessity of identifying relevant spatial scales. Mar Ecol Prog Ser 236: 121-128

Callier MD, Weise AM, McKindsey CW, Desrosiers G (2006) Sedimentation rates in a suspended mussel farm (GreatEntry Lagoon, Canada): biodeposit production and dispersion. Mar Ecol Prog Ser 322:129-141

Callier MD, McKindsey C, Desrosiers G (2007) Multi-scale spatial variations in benthic sediment geochemistry and macrofaunal communities under a suspended mussel culture. Mar Ecol Prog Ser 348:103-115

Callier MD, McKindsey CW, Desrosiers G (2008) Evaluation of indicators used to detect mussel farm influence on the benthos: two case studies in the Magdalen Islands, Eastern Canada. Aquaculture 278:77-88

> Chamberlain J, Fernandes TF, Read P, Nickell TD, Davies IM (2001) Impacts of biodeposits from suspended mussel (Mytilus edulis L.) culture on the surrounding surficial sediments. ICES J Mar Sci 58:411-416

Clarke KR, Gorley RN (2001) Primer v5: user manual/tutorial. PRIMER-E, Plymouth Marine Laboratory, Plymouth

Clynick BG, McKindsey CW, Archambault P (2008) Distribution and productivity of fish and macroinvertebrates in aquaculture sites in the Magdalen Islands (Québec, Canada). Aquaculture 283:103-110

Commito JA (1982) Effects of Lunatia heros predation on the population dynamics of Mya arenaria and Macoma balthica in Maine, USA. Mar Biol 69:187-193

Costa-Pierce BA, Bridger CJ (2002) The role of marine aquaculture facilities as habitats and ecosystems. In: Stickney RR, McVey JP (eds) Responsible marine aquaculture. CABI Publishing, Wallingford, p 105-144

Crawford CM, Macleod CKA, Mitchell IM (2003) Effects of shellfish farming on the benthic environment. Aquaculture 224:117-140

> Danovaro R, Gambi C, Luna GM, Mirto S (2004) Sustainable impact of mussel farming in the Adriatic Sea (Mediterranean Sea): evidence from biochemical, microbial and meiofaunal indicators. Mar Pollut Bull 49:325-333

de Jong RJ (1994) The effects of mussel farming on the benthic environment. MSc thesis, University of Aukland

Dempster T, Sanchez-Jerez P, Bayle-Sempere J, GiménezCasalduero F, Valle C (2002) Attraction of wild fish to seacage fish farms in the south-western Mediterranean Sea: 
spatial and short-term temporal variability. Mar Ecol Prog Ser 242:237-252

Freire J, González-Gurriarán E (1995) Feeding ecology of the velvet swimming crab Necora puber in mussel raft areas of the Ria de Arousa (Galicia, NW Spain). Mar Ecol Prog Ser 119:139-154

> Gaymer CF, Himmelman JH, Johnson LE (2001) Use of prey resources by the seastars Leptasterias polaris and Asterias vulgaris: a comparison between field observations and laboratory experiments. J Exp Mar Biol Ecol 262:13-30

González-Gurriarán E (1986) Seasonal changes of benthic megafauna in the Ría de Muros e Noia (Galicia, NorthWest Spain). II. Decapod crustaceans (Brachyura). Mar Biol 92:201-210

Grant J, Hatcher A, Scott DB, Pocklington P, Shafer CT, Winters GV (1995) A multidisciplinary approach to evaluating impacts of shellfish aquaculture on benthic communities. Estuaries 18:124-144

Grant J, Cranford P, Hargrave B, Carreau M and others (2005) A model of aquaculture biodeposition for multiple estuaries and field validation at blue mussel (Mytilus edulis) culture sites in eastern Canada. Can J Fish Aquat Sci 62: 1271-1285

Hartstein ND, Rowden AA (2004) Effect of biodeposits from mussel culture on macroinvertebrate assemblages at sites of different hydrodynamic regime. Mar Environ Res 57: 339-357

Hartstein ND, Stevens CL (2005) Deposition beneath longline mussel farms. Aquacult Eng 33:192-213

> Howell PT, Molnar DR, Harris RB (1999) Juvenile winter flounder distribution by habitat type. Estuaries 22: 1090-1095

Inglis GJ, Gust N (2003) Potential indirect effects of shellfish culture on the reproductive success of benthic predators. J Appl Ecol 40:1077-1089

Mattsson J, Linden O (1983) Benthic macrofauna succession under mussels, Mytilus edulis L. (Bivalvia), cultured on hanging long-lines. Sarsia 68:97-102

McKindsey CW, Anderson MR, Barnes P, Courtenay S, Landry T, Skinner M (2006a) Effects of shellfish aquaculture on fish habitat. Fish Oceans Can Sci Advis Secretariat Res Doc 2006/011. www.dfo-mpo.gc.ca/csas/Csas/ DocREC/2006/RES2006_011_e.pdf

McKindsey CW, Thetmeyer H, Landry T, Silvert W (2006b) Review of recent carrying capacity models for bivalve culture and recommendations for research and management. Aquaculture 261:451-462

Miron G, Landry T, Archambault P, Frenette B (2005) Effects of mussel culture husbandry practices on various benthic characteristics. Aquaculture 250:138-154

Morrisey DJ, Cole RG, Davey NK, Handley SJ, Bradley A, Brown SN, Madarasz AL (2006) Abundance and diversity of fish on mussel farms in New Zealand. Aquaculture 252: $277-288$

O'Neill SM, Sutterlin AM, Aggett D (1983) The effects of sizeselective feeding by starfish (Asterias vulgaris) on the production of mussels (Mytilus edulis) cultured on nets. Aquaculture 35:211-220

Olaso I (1982) Ecologia de los equinodermos de la Ría de Arosa. Bol Inst Esp Oceanogr 7:4-29

Editorial responsibility: Matthias Seaman, Oldendorf/Luhe, Germany
Paille N, Sainte-Marie B, Brethes JC (2002) Behavior, growth and survival of stage $\mathrm{V}$ lobsters (Homarus americanus) in relation to shelter availability and lobster density. Mar Freshw Behav Physiol 35:203-219

Pearson TH, Rosenberg R (1978) Macrobenthic succession in relation to organic enrichment and pollution of the marine environment. Oceanogr Mar Biol Annu Rev 16:229-311

Powers MJ, Peterson CH, Summerson HC, Powers SP (2007) Macroalgal growth on bivalve aquaculture netting enhances nursery habitat for mobile invertebrates and juvenile fishes. Mar Ecol Prog Ser 339:109-122

Reiss H, Kroncke I (2004) Seasonal variability of epibenthic communities in different areas of the southern North Sea. ICES J Mar Sci 61:882-905

Richard M, Archambault P, Thouzeau G, Desrosiers G (2007) Summer influence of 1 and 2 yr old mussel cultures on benthic fluxes in Grande-Entree lagoon, Iles-de-la-Madeleine (Quebec, Canada). Mar Ecol Prog Ser 338:131-143

Romero P, González-Gurriarán E, Penas E (1982) Influence of mussel rafts on spatial and seasonal abundance of crabs in the Ría de Arousa, North-West Spain. Mar Biol 72:201-210

Sainte-Marie B, Chabot D (2002) Ontogenetic shifts in natural diet during benthic stages of American lobster (Homarus americanus) off the Magdalen Islands. Fish Bull 100: $106-116$

Sanchez-Jerez P, Ramos-Espla A (2000) Changes in fish assemblages associated with the deployment of an antitrawling reef in seagrass meadows. Trans Am Fish Soc 129:1150-1159

Sargent PS, Gregory RS, Schneider DC (2006) Density responses of subarctic coastal marine fish and crabs to artificial reefs. Trans Am Fish Soc 135:348-360

Stehlik LL (1993) Diets of the brachyuran crabs Cancer irroratus, C. borealis, and Ovalipes ocellatus in the New York Bight. J Crustac Biol 13:723-735

Stehlik LL, Mackenzie CL, Morse WW (1991) Distribution and abundance of 4 brachyuran crabs on the Northwest Atlantic shelf. Fish Bull 89:473-492

Stenton-Dozey JME, Jackson LF, Busby AJ (1999) Impact of mussel culture on macrobenthic community structure in Saldanha Bay, South Africa. Mar Pollut Bull 39:357-366

Tenore KR, Gonzalez N (1975) Food chain patterns in the Ría de Arosa, Spain: an area of intense mussel aquaculture. In: Persoone G, Jaspers E (eds) 10th European symposium on marine biology, Vol 2. Universal Press, Wetteren, p 601-619

> Terlizzi A, Benedetti-Cecchi L, Bevilacqua S, Fraschetti S, Guidetti P, Anderson MJ (2005) Multivariate and univariate asymmetrical analyses in environmental impact assessment: a case study of Mediterranean subtidal sessile assemblages. Mar Ecol Prog Ser 289:27-42

Thorne RS, Williams WP, Cao Y (1999) The influence of data transformations on biological monitoring studies using macroinvertebrates. Water Res 33:343-350

Underwood AJ (1997) Experiments in ecology: their logical design and interpretation using analysis of variance. Cambridge University Press, Cambridge

Underwood AJ, Chapman MG (2003) Power, precaution, type II error and sampling design in assessment of environmental impacts. J Exp Mar Biol Ecol 296:49-70

Submitted: August 3, 2007; Accepted: July 29, 2008

Proofs received from author(s): November 6, 2008 